\title{
Influence of soft tissues on mandibular gray scale levels
}

\section{Influência dos tecidos moles sobre os níveis de cinza mandibulares}

\author{
Paulo Henrique Couto Souza* \\ Nilza Pereira da Costa** \\ Elaine Bauer Veeck**
}

\begin{abstract}
The purpose of this study was to analyze the gray levels, expressed in pixels, of the mandibular retromolar region, with regard to the influence of muscular and fat soft tissues near this region. Fifteen dry mandibles were X-rayed with the presence of soft tissue simulators. The radiographs were digitized and evaluated by Digora ${ }^{\circledR}$ software. A one $\mathrm{cm}$ thick layer of wax was used as a simulator of the muscular soft tissue. Animal fat samples of different thicknesses - 0.5, $1.0,1.5$ and $2.0 \mathrm{~cm}$ - were used as a simulator of the fat soft tissue. Results showed that the fat soft tissue simulator influenced the gray level values in pixels of the mandibular retromolar region when analyzed in different thicknesses using the Digora ${ }^{\circledR}$ digitized image software.
\end{abstract}

DESCRIPTORS: Soft tissues; Digora; Bone density; Mandible; Radiography, dental.

\begin{abstract}
RESUMO: O presente trabalho foi desenvolvido com o objetivo de analisar os níveis de cinza, expressos em "pixels", da região retromolar mandibular, considerando a influência dos tecidos moles muscular e, principalmente, adiposo adjacentes a essa região. Para o estudo, 15 mandíbulas secas foram tecnicamente radiografadas, sendo que as radiografias obtidas foram escaneadas e avaliadas pelo programa de imagens digitalizadas Digora ${ }^{\circledR}$. Como simuladores dos tecidos muscular e adiposo, foram utilizadas cera utilidade na espessura de $1,0 \mathrm{~cm}$ e amostras de gordura animal em espessuras diferentes de 0,$5 ; 1,0 ; 1,5$ e 2,0 cm. Os resultados mostraram que o tecido adiposo foi capaz de influenciar a análise dos valores de níveis de cinza em "pixels" da região retromolar mandibular quando estudado em espessuras diferentes pelo programa de imagens digitalizadas Digora ${ }^{\circledR}$.
\end{abstract}

DESCRITORES: Tecidos moles; Digora; Densidade óssea; Mandíbula; Radiografia dentária.

\section{INTRODUCTION}

The evaluation of mandibular bone density through in vitro digitized images renders a more comprehensive evaluation, which is not possible with radiographic film sensitizing, mainly due to the absence of muscular and fat soft tissues that can interfere in this sensitizing. These soft tissues compromise directly the gray level mensuration in digitized radiographs and consequently the evaluation of bone density expressed in pixel values.

Concern over the importance of bone density studies, regarding the presence of muscular and fat soft tissues, comes from researches such as the those conducted by Henderson et al. ${ }^{10}$ (1995) and Baumgartner et al. ${ }^{4}$ (1996), who investigated the possible correlation between an increase in fat tissue and a lower degree of osteoporosis in women during menopause or between the mechanical action of muscular force and higher bone density found in people who exercise regularly.

In a effort to simulate muscular and fat soft tissues in in vitro studies, authors such as Buhl et al. ${ }^{6}$ (1991) and Laskey et al. ${ }^{11}$ (1992) utilized tissues of animal origin to estimate the effect of their thickness and composition on bone density (BD), the total bone mineral quantity (BMD) and the bone mineral content (BMC) through dual energy X-ray absorptiometry (DEXA). On the other hand, a number of scientific studies ${ }^{1,2,7,9,12,21,22}$ have utilized material of different compositions such as acrylic resin, plastic and water as soft tissue simulators.

Some studies ${ }^{3,13,15,20}$ have also investigated mandibular bone density, however, through gray level analysis in pixels utilizing dry mandibles and considering the presence of soft tissue simulators in their studies.

Therefore, the main objective of this study was to evaluate the influence of different thicknesses of fat soft tissue simulators on the analysis of gray levels in the mandibular retromolar region, using

\footnotetext{
* Associate Professor, School of Dentistry, Pontifical Catholic University of Paraná

** Full Professors, School of Dentistry, Pontifical Catholic University of Rio Grande do Sul.
} 
Ultraspeed film and the Digora ${ }^{\circledR}$ digitized image program.

\section{METHODOLOGY}

This study was submitted to and approved by the Committee of Ethics and Scientific Research of the School of Dentistry, Pontifical Catholic University, Rio Grande do Sul.

In order to obtain the fat soft tissue simulators, four plastic containers were constructed, with different thicknesses of $0.5 \mathrm{~cm}, 1.0 \mathrm{~cm}, 1.5 \mathrm{~cm}$ and $2.0 \mathrm{~cm}$. For the muscular tissue simulator, $1.0 \mathrm{~cm}$ thick wax was chosen, according to the study of Souza et al. ${ }^{20}$ (1999). The fat tissue samples were of bovine origin and similar to the ones found in the subcutaneous tissue of the mandibular retromolar region. Afterwards, the samples were kept inside each container.

Finally, five simulators were obtained from the soft tissues of the mandibular retromolar region with the utilization of plastic containers, wax, and fat tissue samples of bovine origin, classified as follows:

- Fat tissue simulators (FT)

- Container 1 - Simulator FT1 -

Dimensions: $4.0 \mathrm{~cm} \times 3.0 \mathrm{~cm} \times 0.5 \mathrm{~cm}$.

- Container 2 - Simulator FT2 -

Dimensions: $4.0 \mathrm{~cm} \mathrm{x} 3.0 \mathrm{~cm} \times 1.0 \mathrm{~cm}$.

- Container 3 - Simulator FT3 -

Dimensions: $4.0 \mathrm{~cm} \times 3.0 \mathrm{~cm} \times 1.5 \mathrm{~cm}$.

- Container 4 - Simulator FT4 -

Dimensions: $4.0 \mathrm{~cm} \times 3.0 \mathrm{~cm} \times 2.0 \mathrm{~cm}$.

- Muscular tissue simulator (MT)

- Utility wax (Epoxiglass, Epoxiglass

Ind. Com. de Produtos Químicos Ltda., Diadema, SP, Brazil) - Simulator MT -

Dimensions: $4.0 \mathrm{~cm} \times 3.0 \mathrm{~cm} \times 1.0 \mathrm{~cm}$.

A simulation criterion of muscular and fat soft tissues of the mandibular retromolar region was established to obtain radiographs, in such way that MT and FT1 simulators, duly positioned as described above, were in a closer position than they would be in a study with human beings. Mandible radiographs in this condition were considered as controls for a later comparison with the other radiographs taken in which only fat tissue simulators were substituted during the taking of radiographs. A previous test was also performed, following the same conditions of the study, with the objective of standardizing the time of radiographic exposure, considering the utilization of Kodak Ultraspeed film. As per the manufacturer's directions for the adjustment of exposure time and after the evalu- ation of the radiographs by a radiology specialist, the exposure time of $0.40 \mathrm{~s}$ for the utilized film was obtained. In order to achieve a standardization of radiographs, a positioner device was made with the objective of keeping radiographic films parallel and near the area to be radiographed.

Each radiographic film was placed in the positioner in such way that it would enclose the analyzed retromolar regions. Afterwards, simulators were positioned in juxtaposition with the vestibular cortical area of the lower molar region, including the retromolar area of interest. In this way, a set composed of radiographic film, mandible and simulators, parallel among themselves, was obtained (Figure 1). The central beam of X-rays was directed perpendicularly to the film and at a standardized distance of $25 \mathrm{~cm}$.

Three radiographs were taken for each specific situation. All taken radiographs were made utilizing periapical film Ultraspeed Lot 3100720 (Kodak Ultraspeed, size 2, DF-58, Rochester, USA). For each radiography, an X-ray device (Spectro 70 X - Dabi Atlante, Ribeirão Preto, SP, Brazil) with a voltage of $70 \mathrm{kVp}$ and a current of $8 \mathrm{~mA}$ was used and a $2.5 \mathrm{mmAl}$ filter. The processing was executed in an automatic processor machine (automatic processor Air Technics Inc. AT 2000, Hicksville, New York, USA) for 4.5 minutes, at a temperature of about $28^{\circ} \mathrm{C}$. A total of 360 periapical radiographs were obtained, and they were handled with special gloves to avoid digital impressions that could harm further analysis of gray levels. Before the optic analysis of gray levels through the Digora ${ }^{\circledR}$ software (Digora for Windows 1.51, Soredex, Helsinki, Finland), all radiographic film

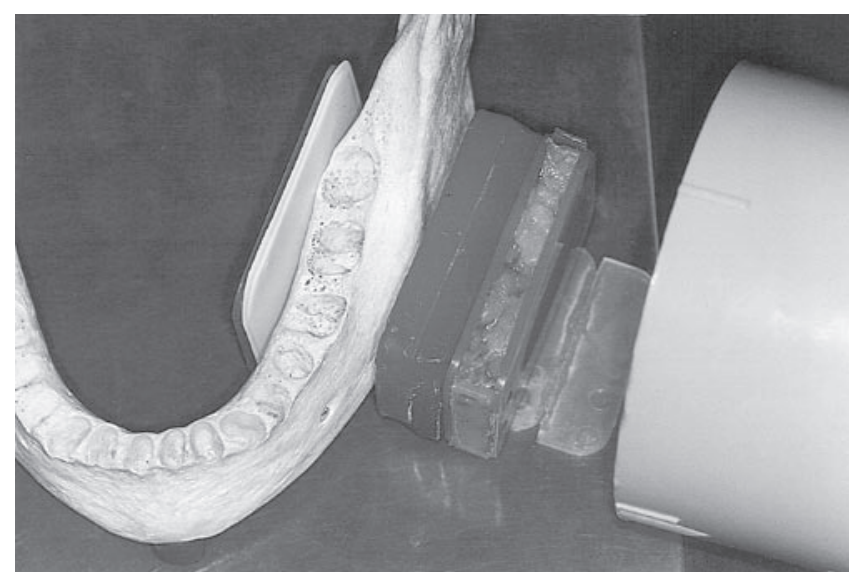

FIGURE 1 - Radiography taken with the set composed by radiographic film, mandible and simulators, parallel among each other. 
was scanned, and the corresponding images were filed in a computer in tiff format (tagged image file format). For this purpose, an appropriate flat-bed scanner (Scanjet 6100 C/T, Hewlett Packard, San Diego, USA) was used, through which the groups of radiographic films that correspond to each retromolar region were positioned on the scanner bed. The respective projections of the identifying trade marks were turned toward the bed face and aligned in three columns of eight films each. This way, the HP Desk Scan II program allowed the image to be adjusted for size, mode and resolution according to the functions: type (sharp black and white photo), path (screen), scaling (475\%) and size $(242 \mathrm{~KB})$.

A specific file was created for the gray level optic analysis in the retromolar regions by means of the Digora ${ }^{\circledR}$ program, so that the previously scanned images could be located on the hard drive, according to the soft tissue simulator type (MTFT 1, 2, 3, 4) and imported to the program. Each image was measured according to the gray levels expressed in pixels, through the "density measurement" function in delimited areas inside the retromolar image (Figure 2).

For this purpose, an informative table "cursor" was used in order to make an orientation of these areas possible through $\mathrm{x}$ (horizontal) and $y$ (vertical) axis coordinates. Therefore, the areas were selected trying, at first, to avoid some anatomic structures such as the mandibular canal and the cortical strips in the oblique and mylohyoid orientation, so that the exact area could be identified, according to the coordinates found and visualized in the function "start", regarding the

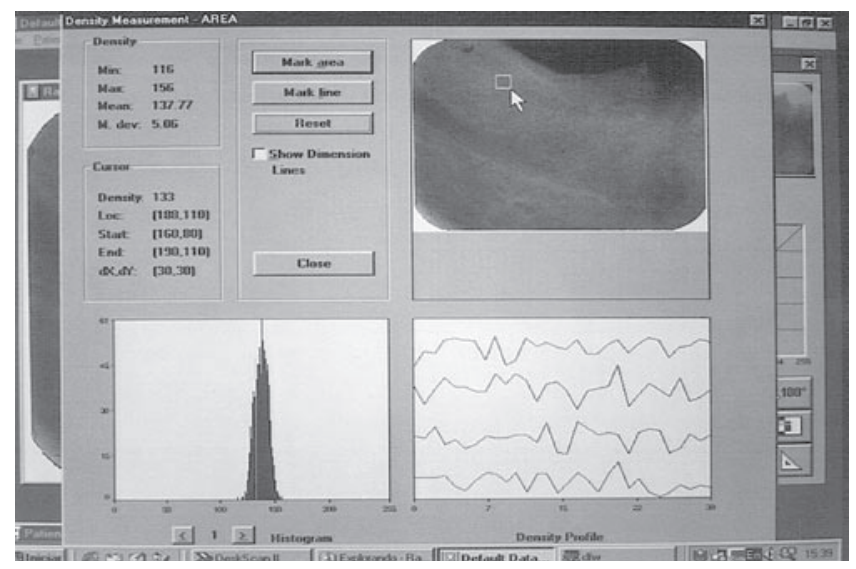

FIGURE 2 - The Digora ${ }^{\circledR}$ program screen, presenting the functions necessary for the mensuration of gray levels. initial point of demarcation. On the other hand, the size of the area was of approximately $2 \mathrm{~mm}^{2}$, which corresponds to $30 \times 30$ pixels, identified by the coordinates $\mathrm{dX}$ and $\mathrm{dY}$, considering that each pixel measured $70 \mu \mathrm{m}$. For each analyzed area, the initial coordinates were taken note of and the average values of gray levels were described by the function "mean".

\section{RESULTS}

The results of the present study, according to gray level values in pixels, were obtained for thicknesses of soft tissue simulators evaluated by Anova and the Tukey's statistical tests for variance analysis.

Tables 1 to 4 show the values obtained from thicknesses of soft tissue simulators, in the Digora ${ }^{\circledR}$ program using Ultraspeed film.

\section{DISCUSSION}

The influence of muscular and fat tissues, described by the study of Brot et al. ${ }^{5}$ (1997) on bone density alterations, without a doubt, is better explored with the utilization of specific equipment, such as dual energy X-ray absorptiometry (DEXA) $)^{4,10,16,17}$. It is a technology that is able to distinguish different degrees of photonic or radiographic attenuation, originated in tissues with different molecular structures, such as bones or fat and muscular soft tissues, adjacent to the studied

TABLE 1 - Comparison between gray level values, in pixels, obtained in each thickness of soft tissue simulators, analyzed in the Digora ${ }^{\circledR}$ program using U1traspeed film. FO-PUCRS, 2001.

\begin{tabular}{c|c|c|c}
\hline \hline Simulator & $\mathrm{n}$ & Gray level (pixels) & $\mathrm{p}$ \\
\hline MTFT1(control) & 90 & 116.83 & $0.05^{*}$ \\
\hline MTFT2 & 90 & 125.16 & 0.000 \\
\hline MTFT3 & 90 & 130.58 & 0.000 \\
\hline MTFT4 & 90 & 136.62 & 0.000 \\
\hline
\end{tabular}

*Statistically significant level; n: sample size.

TABLE 2 - Comparison between gray level values, in pixels, obtained between thicknesses MTFT2 and MTFT3 of soft tissue simulators, analyzed in the Digora ${ }^{\circledR}$ program using Ultraspeed film. FO-PUCRS, 2001.

\begin{tabular}{c|c|c|c}
\hline \hline Simulator & $\mathrm{n}$ & Gray level (pixels) & $\mathrm{p}$ \\
\hline MTFT2 & 90 & 125.16 & $0.020^{*}$ \\
\hline MTFT3 & 90 & 130.58 & 0.020 \\
\hline \hline
\end{tabular}

$*$ Statistically significant value for $\mathrm{p}=5 \%$; $\mathrm{n}$ : sample size. 
TABLE 3 - Comparison between gray level values, in pixels, obtained between thicknesses MTFT2 and MTFT4 of soft tissue simulators, analyzed in the Digo$\mathrm{ra}^{\circledR}$ program using Ultraspeed film. FO-PUCRS, 2001.

\begin{tabular}{c|c|c|c}
\hline \hline Simulator & $\mathrm{n}$ & Gray level (pixels) & $\mathrm{p}$ \\
\hline MTFT2 & 90 & 125.16 & $0.000^{*}$ \\
\hline MTFT4 & 90 & 136.62 & $0.000^{*}$ \\
\hline \hline
\end{tabular}

*Statistically significant for $\mathrm{p}=0.5 \%$; $\mathrm{n}$ : sample size.

TABLE 4 - Comparison between gray level values, in pixels, obtained between thicknesses MTFT3 and MTFT4 of soft tissue simulators, analyzed in the Digora ${ }^{\circledR}$ program using Ultraspeed film. FO-PUCRS, 2001.

\begin{tabular}{c|c|c|c}
\hline \hline Simulator & $\mathrm{n}$ & Gray level (pixels) & $\mathrm{p}$ \\
\hline MTFT3 & 90 & 130.58 & $0.006^{*}$ \\
\hline MTFT4 & 90 & 136.62 & $0.006^{*}$ \\
\hline \hline
\end{tabular}

*Statistically significant for $\mathrm{p}=0.5 \%$; $\mathrm{n}$ : sample size.

region. As bone density, in general, is derived from this attenuation degree, its quantification becomes more precise when one considers the influence of these tissues.

The present study tried to confirm the need for reproducing, as closely as possible, in vivo studies $^{1,2,6,7,9,11,12,21,22}$. In these studies the authors made use of materials and samples of animal origin, which would serve as a model to simulate bone, muscle, and fat, with a view to obtaining a better representation of the real situation.

Consequently, this research searched for a better representation of an in vivo study, utilizing utility wax according to the study of Souza et al. ${ }^{20}$ (1999) and fat tissue samples as suggested by Buhl et al. ${ }^{6}$ (1991) and Laskey et al. ${ }^{11}$ (1992). Besides this aspect, the study also questioned the influence of different thicknesses related to fat tissue, which assumes distinct standards according to each individual or nutritional condition on mandibular bone density analyzed according to gray levels in digitized images. The results obtained in tables one, two, three and four confirmed that, in fact, small variations of about $5.0 \mathrm{~mm}$ in the thickness of fat tissue are able to generate different

\section{REFERENCES}

1. Alvares LC, Tavano O, Souza Freitas JAS. A comparative study of some materials used as substitutes for soft tissue, in reference to the absorption of X-rays and scattering of secondary radiation. Estomatol Cult 1969;3:15366. results, statistically corroborated, of mandibular bone density assessed by an optic analysis of gray levels.

This fact allows the inference that more obese individuals could present action synergism of the fat tissue in relation to its mandibular bone structure, when evaluated as in the present study, resulting from the metabolic action of the tissue itself, according to the studies of Reid et al. ${ }^{16,17}$ (1992), Baumgartner et al. ${ }^{4}$ (1996), Brot et al. ${ }^{5}$ (1997), as well as a larger attenuation of the radiographic beam, which, on the other hand, would sensitize the film in smaller proportions, which would be shown, in the final analyses, in higher pixel values. This larger attenuation of the X-ray beam confirms that the fat tissue, even if it does not have a high atomic number in its molecular structure, as occurs in bone tissue, for example, is able to hinder the passage of the beam, affecting, therefore, the sensitizing of films as well as the optic reading of gray levels in pixels.

On the other hand, the optic analysis of gray level in pixels or in equivalent millimeters of aluminum (mmAl) of face bones, has been increasingly investigated. Based on this context, this research study establishes a continuity of the research ${ }^{3,8,13-}$ 15,18,19 carried out mainly by Souza et al. ${ }^{20}$ (1999), who in their study investigated the influence of the muscular tissue on the optic analysis of mandibular retromolar bone density in digitized images. This bone density evaluation method, in spite of not being very precise compared to the dual energy X-ray absorptiometry (DEXA), is presented as another important alternative of diagnosing alterations and pathologies which affect the bone tissue.

\section{CONCLUSION}

Based on the developed methodology and the obtained results in the present study, it was possible to conclude that the presence of muscular soft tissue and chiefly the fat soft tissue simulators adjacent to the studied region had an important role in the determination of gray levels for the mandibular retromolar region.

2. Attaelmanan A, Borg E, Grondahl HG. Digitisation and display of intra-oral films. Dentomaxillofac Radiol 2000;29:97-102.

3. Barros FJBC, Brito JHM, Veeck EB, Costa NP. Optic evaluation of bone density in the retromolar region through 
digitized images: study in "post-mortem" mandibles. Odontociência 2001;16:103-10.

4. Baumgartner RN, Stauber PM, Koehler KM, Romero L, Garry JP. Associations of fat and muscle masses with bone mineral in elderly men and women. Am J Clin Nutr 1996;63:365-72.

5. Brot C, Jensen LB, Sorensen OH. Bone mass and risk factors for bone loss in perimenopausal Danish women. J Intern Med 1997;242:505-11.

6. Buhl K, Heymsfield S, Aulet M, Wang J, Pierson RN, Lichtman S. Effect of tissue thickness on bone density and bone mineral by dual energy X-ray. In: $75^{\text {th }}$ Annual Meeting Atlanta. The Faseb Journal; 1991. p. A924.

7. Cook JE, Cunningham JL. The assessment of fracture healing using dual X-ray absorptiometry: a feasibility study using phantoms. Phys Med Biol 1995;40:119-36.

8. Garcia RS, Costa NP, Souza ACA. Bone density: a study of the area between lateral incisors and eye teeth in the jawbone of humans. Odontociência 1996;11:7-25.

9. Hayakawa Y, Farman AG, Kelly MS, Kuroyanagi K. Intraoral radiographic storage phosphor image mean pixel values and signal-to-noise ratio. Oral Surg Oral Med Oral Pathol Oral Radiol Endod 1998;86:601-5.

10. Henderson NK, Price RI, Cole JH, Gutteridge DH, Bhagat CI. Bone density in young women is associated with body weight and muscle strength but not dietary intakes. J Bone Mineral Res 1995;10:384-91.

11. Laskey MA, Lyttle KD, Flaxman ME, Barber RW. The influence of tissue depth and composition on the performance of the Lunar dual-energy X-ray absorptiometer wholebody scanning mode. Eur J Clin Nutr 1992;46:39-45.

12. Magalhaes SD, Goncalves OD, Rizzo P. Scattering of $60 \mathrm{keV}$ photons by biological material and influence in diagnostic radiology. Med Phys 1996;23:1635-42.

13. Meurer E. Optic reading analyses of bone density of the parasymphyseal region through a digital radiography system, using soft tissue simulators [Master's Thesis].
Porto Alegre: School of Dentistry of the Pontifical Catholic University of Rio Grande do Sul; 2000.

14. Puppin AAC, Costa NP, Garcia RS. Bone density analysis through optic reading in the region of third lower molars in dry mandibles. Odontociência 1998;13:151-65.

15. Puppin AAC, Souza PHC, Costa NP, Veeck EB. The implant influence in the gray values of digital images in the peri-implantar region. Odontociência 2001;16:209-21.

16. Reid IR, Ames R, Evans MC, Sharpe S, Gamble G, France $\mathrm{JT}$, et al. Determinants of total body and regional bone mineral density in normal postmenopausal women - a key role for fat mass. Clin Endocrinol Metab 1992;75:4551.

17. Reid IR, Plank LD, Evans MC. Fat mass is an important determinant of whole body mineral density in normal postmenopausal women but not in men. A key role for fat mass. J Clin Endocrinol Metabol 1992;75:779-82.

18. Scarparo HC, Costa NP, Souza ACA. Presentation of an exploratory methodology for bone density analyses in mandible. Odontociência 1995;10:29-45.

19. Soares E, Costa NP, Garcia RS. Optic reading analyses of bone density utilizing two luminous sources. Odontociência 1997;12:131-43.

20. Souza PHC, Costa NP, Puppin AAC. Optic analyses of mandibular retromolar bone density through digitized images, utilizing soft tissue simulators. Odontociência 1999;14:27-53.

21. Svanaes DB, Moystad A, Risnes S, Larhenn TA, Grondahl HG. Intraoral storage phosphor radiography for approximal caries detection and effect of image magnification. Oral Surg Oral Med Oral Pathol Oral Radiol Endod 1996;82:94-100.

22. Wenzel A, Borg E, Hintze H, Grondahl HG. Accuracy of caries diagnosis in digital images from charge-coupled device and storage phosphor systems: an in vitro study. Dentomaxillofac Radiol 1995;24:250-54.

Received for publication on Dec 04, 2002 Sent for alterations on Aug 14, 2003 Accepted for publication on Sept 24, 2003 